Рекомендована д. фрармац. наук, профр. Т. А. Грошовим

УДК 615.454.122: 615.238:615.014

DOI 10.11603/2312-0967.2018.1.8604

\title{
ЕКСПЕРИМЕНТАЛЬНЕ ОБҐРУНТУВАННЯ СКЛАДУ НАЗАЛЬНОГО ГЕЛЮ ПІД УМОВНОЮ НАЗВОЮ «ФІТОРИН-ПЛЮС»
}

\author{
(ㄱ І. А. Карпенко, Т. Г. Ярних, О. А. Рухмакова \\ Національний фрармацевтичний університет, Харків \\ rukhmakovaolga@gmail.com
}

\begin{abstract}
Мета роботи. Експериментальне обґрунтування складу назального гелю під умовною назвою «Фіторин-плюс». Матеріали і методи. 3 метою визначення раціональної концентрації екстракту кореня солодки та ефірних олій евкаліпту прутоподібного і сосни сибірської у складі гелю були проведені мікробіологічні дослідження на базі кафредри мікробіології, вірусології та імунології Національного фрармацевтичного університету в лабораторії мікробіологічних та імунологічних досліджень методом дифузії в агар 3 використанням еталонних штамів мікроорганізмів: Staphylococcus aureus ATCC 25923, Escherichia coli ATCC 25922, Pseudomonas aeruginosa ATCC 27853, Candida albicans ATCC 885/653. Дослідження з вивчення противірусної активності здійснювали на базі Державної установи «Інститут мікробіології та імунології ім. І. І. Мечникова АМН України».

Результати й обговорення. На підставі проведених досліджень були обґрунтовані раціональні концентрації діючих речовин у складі назального гелю «Фіторин-плюс»: екстракту кореня солодки - 3 \%, есрірної олії евкаліпту прутоподібного - 2 \%, ефрірної олії сосни сибірської - 1 \%. Отримані дані були підтверджені при подальшому експериментальному вивченні антимікробних і противірусних властивостей готової лікарської фрорми.

Висновки. Експериментально обґрунтовано вибір діючих речовин назального гелю під умовною назвою «Фіторинплюс» для лікування ринітів. На підставі даних проведених мікробіологічних досліджень обґрунтовано концентрацію екстракту кореня солодки й ефрірних олій у складі лікарського препарату. Вперше встановлено противірусну дію екстракту кореня солодки відносно аденовірусу. Показано, що розроблений назальний гель є перспективним для подальшого використання в терапії ринітів.
\end{abstract}

Ключові слова: назальний гель; солодка гола; ефірні олії; склад; експериментальне обґрунтування.

Вступ. Риніт - широко розповсюджене захворювання слизової оболонки порожнини носа, яке виявляють у загальній популяції людей із частотою понад 15 \%. Численні дослідження останніх років вказують також на збільшення випадків виникнення риніту й серед дітей.

Відомо, що у 45-60 \% населення з ринітом надалі розвивається таке системне автоімунне захворювання, як бронхіальна астма. Нерідко риніт перебігає на тлі атопічного дерматиту або інших алергічних захворювань, що ускладнює перебіг процесу і впливає на ефективність його терапії. Крім того, необхідно зазначити, що в етіології розвитку ринітів важливе значення відіграють аденовіруси, які призводять до зміни реактивності імунної системи та полівалентної сенсибілізації організму людини в цілому $[1,2]$.

Незважаючи на різноманіття існуючих методів лікування, не завжди вдається досягти стійкого клінічного ефекту, що посилюється складністю патогенезу риніту. Необхідність комбінованої терапії даної патології підтверджена численними клінічними, функціональними і морфологічними дослідженнями.

3 метою симптоматичного лікування ринітів найчастіше застосовують краплі для носа, інтраназальні аерозолі (спреї), назальні гелі, мазі, креми та капсули. Серед переваг назальних гелів, насамперед, варто виділити пролонгованість їх дії, наявність зволожувальної дії на слизову оболонку порожнини носа при її сухості, легкість видалення з поверхні рук та одягу тощо [3, 4].

Наявний асортимент лікарських препаратів на сучасному фрармацевтичному ринку України пропонує досить широкий вибір засобів для симптоматичної терапії ринітів, однак частка саме назальних гелів серед них $є$ дуже невисокою. Саме тому створення нового назального гелю на основі природної сировини із антимікробною та противірусною дією (відносно аденовірусів) $€$ актуальним завданням сучасної медицини і фрармації.

Мета роботи - експериментальне обґрунтування складу назального гелю під умовною назвою «Фіторин-плюс».

Матеріали і методи. Вивчивши асортимент і фрармакологічні властивості лікарських рослин, які можуть бути використані в терапії ринітів як діючих речовин для створення назального гелю для лікування даної патології, ми обрали екстракт кореня солодки голої та есрірні олії евкаліпту прутоподібного і сосни сибірської.

ISSN 2312-0967. Pharmaceutical review. 2018. № 1 
Фармацевтична технологія, біофармація, гомеопатія Pharmaceutical technology, biopharmacy, homeopathy

Лікувальні властивості солодки голої використовують здавна. Вона ефективна при застудних захворювань не лише у дорослих, а також у дітей. Сироп на основі екстракту солодки набув широкого застосування в педіатрії, оскільки виготовлений із натуральної сировини і є безпечним засобом, навіть для маленьких дітей.

Відомо, що солодка гола має виражену противірусну дію. При цьому дослідження з вивчення противірусної активності екстракту коренів солодки відносно аденовірусів не проводили [5].

Ефірна олія евкаліпту прутоподібного застосовують при ринітах як потужний бактерицидний засіб завдяки вмісту у своєму складі фреландрену і аромадендрену. Евкаліптова олія $€$ ефективною навіть при задавнених ринітах і синуситах, скорочує час лікування даних патологій, добре очищає носові ходи від густого слизу. Сосна сибірська проявляє противірусну та антимікробну дію відносно Staphylococcus aureus, Escherichia coli, Pseudomonas aeruginosa, Candida albicans, Aspergillus niger та ін., що мають етіопатогенетичне значення у розвитку ринітів [6].

3 метою обґрунтування раціональної концентрації екстракту кореня солодки та ефрірних олій евкаліпту прутоподібного і сосни сибірської у складі назального гелю «Фіторин-плюс» були проведені мікробіологічні дослідження.

Вивчення антимікробної активності проводили на базі кафедри мікробіології, вірусології та імунології Національного фрармацевтичного університету в лабораторії мікробіологічних і імунологічних досліджень під керівництвом д. мед. наук, проф. Н. І. Філімонової.

Визначення антибактеріальних властивостей препарату здійснювали методом дифузії в агар із використанням еталонних штамів мікроорганізмів: Staphylococcus aureus ATCC 25923, Escherichia coli ATCC 25922, Pseudomonas aeruginosa ATCC 27853, Candida albicans ATCC 885/653.

Дослідження 3 вивчення противірусної активності здійснювали на базі Державної установи «Інститут мікробіології та імунології ім. І. І. Мечникова АМН України» під керівництвом д. біол. наук, профр. Л. А. Панченко з використанням аденовірусу 3-го типу 3 інфрекційним титром $10^{-4}$. Для виявлення противірусної дії екстракту кореня солодки відносно аденовірусу була використана реакція нейтралізації на культурі клітин VERO.

Результати й обговорення. Для визначення антибактеріальної чутливості екстракту кореня солодки були приготовлені його 2 \%, 3 \%, 4 \%, 5 \% і 7 \% водні розчини, апробовані на штамах культур, наведених у таблиці 1.

Як видно з даних таблиці 1, максимальні діаметри зон затримки росту мікроорганізмів відзначаються для розчину екстракту кореня солодки з концентрацією 5 \%, подальше збільшення його концентрації не призводить до посилення антимікробної активності.

Досліджуваний зразок має помірну антимікробну дію відносно еталонних штамів Staphylococcus aureus ATCC 25923 і Escherichia coli ATCC 25922, при цьому активність щодо еталонних штамів Pseudomonas aeruginosa відсутня.

Відносно грибів роду Candida 5 \% розчин екстракту кореня солодки має виражену протигрибкову дію, діаметр зон затримки росту еталонних штамів Candida albicans ATCC 885/653 становить $(31,6 \pm 1,6)$ мм.

У таблицях 2 і 3 наведено дані щодо вивчення антимікробної активності спиртових розчинів ефрірних олій евкаліпту прутоподібного і сосни сибірської.

Згідно з даними таблиці 2, розчин ефрірної олії евкаліпту прутоподібного в концентрації 2 \% має виражену антимікробну дію відносно еталонних штамів Staphylococcus aureus ATCC 25923 i Escherichia coli ATCC 25922, діаметри зон затримки росту мікроорганізмів складають відповідно $(22,2 \pm 1,4)$ мм і $(13,8 \pm 1,2)$ мм.

Протигрибкова активність розчину ефрірної олії евкаліпту прутоподібного значною нижча від аналогічної в розчину екстракту кореня солодки, так само відзначається й повна відсутність антимікробної дії щодо Pseudomonas aeruginosa.

Дані таблиці 3 показують, що розчин ефрірної олії сосни сибірської має помірно виражену антимікробну активність відносно досліджуваних еталонних штамів мікроорганізмів порівняно з іншими діючими речовинами, однак на відміну від них проявляє антимікробну дію відносно Pseudomonas aeruginosa. Оптимальною визначена її концентрація 1 \%.

Таблиця 1. Антимікробна активність розчинів екстракту кореня солодки

\begin{tabular}{|c|c|c|c|c|}
\hline \multirow{2}{*}{ Концентрація розчину, \% } & \multicolumn{4}{|c|}{ Діаметри зон затримки росту, мм } \\
\cline { 2 - 5 } & $\begin{array}{c}\text { St. aureus } \\
\text { ATCC 25923 }\end{array}$ & $\begin{array}{c}\text { E. coli } \\
\text { ATCC 25922 }\end{array}$ & $\begin{array}{c}\text { Ps. aeruginosa } \\
\text { ATCC 27853 }\end{array}$ & $\begin{array}{c}\text { C. albicans } \\
\text { ATCC 885/653 }\end{array}$ \\
\hline 2 & $12,3 \pm 0,5$ & $15,8 \pm 1,7$ & ріст & $21,0 \pm 1,8$ \\
\hline 3 & $13,3 \pm 2,5$ & $16,8 \pm 2,3$ & ріст & $24,5 \pm 1,8$ \\
\hline 4 & $17,6 \pm 1,8$ & $20,8 \pm 2,3$ & ріст & $24,8 \pm 1,2$ \\
\hline 5 & $19,8 \pm 2,4$ & $23,6 \pm 1,6$ & ріст & $31,6 \pm 1,6$ \\
\hline 7 & $18,0 \pm 1,6$ & $21,0 \pm 1,7$ & ріст & $25,2 \pm 1,5$ \\
\hline
\end{tabular}

Примітка: $\mathrm{n}=5 ; \mathrm{P}=95 \%$.

ISSN 2312-0967. Фармацевтичний часопис. 2018. № 1 
Фармацевтична технологія, біофармація, гомеопатія Pharmaceutical technology, biopharmacy, homeopathy

Таблиця 2. Антимікробна активність розчину ефрірної олії евкаліпту прутоподібного

\begin{tabular}{|c|c|c|c|c|}
\hline \multirow{2}{*}{ Концентрація ефрірної олії, \% } & \multicolumn{4}{|c|}{ Діаметри зон затримки росту, мм } \\
\cline { 2 - 5 } & $\begin{array}{c}\text { St. aureus } \\
\text { ATCC } 25923\end{array}$ & $\begin{array}{c}\text { E. coli } \\
\text { ATCC 25922 }\end{array}$ & $\begin{array}{c}\text { Ps. aeruginosa } \\
\text { ATCC 27853 }\end{array}$ & $\begin{array}{c}\text { C. albicans } \\
\text { ATCC 885/653 }\end{array}$ \\
\hline 1 & $17,3 \pm 1,1$ & $12,3 \pm 1,4$ & ріст & $12,8 \pm 1,4$ \\
\hline 1,5 & $20,1 \pm 1,5$ & $12,6 \pm 1,1$ & ріст & $13,2 \pm 1,3$ \\
\hline 2 & $22,2 \pm 1,4$ & $13,8 \pm 1,2$ & ріст & $14,6 \pm 1,5$ \\
\hline 2,5 & $19,9 \pm 1,2$ & $12,4 \pm 1,5$ & ріст & $14,1 \pm 1,2$ \\
\hline
\end{tabular}

Примітка: $\mathrm{n}=5 ; \mathrm{P}=95 \%$.

Таблиця 3. Антимікробна активність розчину ефрірної олії сосни сибірської

\begin{tabular}{|c|c|c|c|c|}
\hline \multirow{2}{*}{ Концентрація есрірної олії, \% } & \multicolumn{4}{|c|}{ Діаметри зон затримки росту, мм } \\
\cline { 2 - 5 } & $\begin{array}{c}\text { St. aureus } \\
\text { ATCC 25923 }\end{array}$ & $\begin{array}{c}\text { E. coli } \\
\text { ATCC 25922 }\end{array}$ & $\begin{array}{c}\text { Ps. aeruginosa } \\
\text { ATCC 27853 }\end{array}$ & $\begin{array}{c}\text { C. albicans } \\
\text { ATCC 885/653 }\end{array}$ \\
\hline 0,5 & $8,1 \pm 1,4$ & $11,3 \pm 1,5$ & $13,1 \pm 1,6$ & $12,2 \pm 1,5$ \\
\hline 1 & $9,3 \pm 1,2$ & $12,5 \pm 1,4$ & $14,1 \pm 1,3$ & $13,4 \pm 1,6$ \\
\hline 1,5 & $8,6 \pm 1,9$ & $11,8 \pm 1,6$ & $13,8 \pm 1,4$ & $12,7 \pm 1,3$ \\
\hline 2 & $8,1 \pm 1,2$ & $11,4 \pm 1,2$ & $13,7 \pm 1,6$ & $12,5 \pm 1,4$ \\
\hline
\end{tabular}

Примітка: $\mathrm{n}=5 ; \mathrm{P}=95 \%$.

При проведенні подальшого експериментального вивчення антимікробних властивостей суміші досліджуваних субстанцій було доведено синергізм їх дії (табл. 4).

3 огляду на існуючі дані щодо противірусної дії солодки голої відносно ДНК- і РНК-вірусів, проведено дослідження із визначення противірусної активності екстракту кореня солодки відносно аденовірусу. До- слідження проводили з використанням реакції нейтралізації на культурі тканин VERO. В експерименті використано штам аденовірусу 3-го типу 3 інфекційним титром $10^{-4}$ (табл. 5).

Як видно із наведених у таблиці 5 даних, досліджуваний зразок затримував репродукцію аденовірусу на 1-2 розведення, що свідчить про перспективність

Таблиця 4. Антимікробна активність суміші досліджуваних субстанцій

\begin{tabular}{|c|c|c|c|c|}
\hline \multirow{2}{*}{ Зразок } & \multicolumn{3}{|c|}{ Діаметри зон затримки росту, мм } \\
\cline { 2 - 5 } & $\begin{array}{c}\text { St. aureus } \\
\text { ATCC 25923 }\end{array}$ & $\begin{array}{c}\text { E. coli } \\
\text { ATCC 25922 }\end{array}$ & $\begin{array}{c}\text { Ps. aeruginosa } \\
\text { ATCC 27853 }\end{array}$ & $\begin{array}{c}\text { C. albicans } \\
\text { ATCC 885/653 }\end{array}$ \\
\hline $\begin{array}{c}\text { Екстракт кореня солодки 3\% } \\
\text { + есрірна олія евкаліпту 2 \%+ } \\
\text { ефрірна олія сосни 1 \% }\end{array}$ & $29,6 \pm 1,4$ & $31,2 \pm 1,7$ & $14,1 \pm 1,3$ & $38,7 \pm 1,2$ \\
\hline
\end{tabular}

Примітка: $\mathrm{n}=5 ; \mathrm{P}=95 \%$.

Таблиця 5. Противірусна активність екстракту кореня солодки відносно аденовірусу

\begin{tabular}{|c|c|c|}
\hline \multirow{4}{*}{ Контроль } & \multicolumn{2}{|c|}{$\begin{array}{c}\text { Iнфекційний титр вірусів у реакції нейтралізації на культурі тканини } \\
\text { VERO до і після культивування з екстрактом кореня солодки }\end{array}$} \\
\hline & \multicolumn{2}{|c|}{ Аденовірус } \\
\hline & до & після \\
\hline & $10^{-4}$ & $10^{-2}$ \\
\hline Контроль тест-вірусів (100 ТЦД & \multicolumn{2}{|c|}{ Цитопатогенна дія тест-вірусів (+++) } \\
\hline Контроль культури тканини VERO & \multicolumn{2}{|c|}{$\begin{array}{l}\text { Відсутність ознак дегенерації клітин на момент реєстрації } \\
\text { результатів експерименту }\end{array}$} \\
\hline
\end{tabular}

Примітка: $\mathrm{n}=5 ; \mathrm{P}=95 \%$.

ISSN 2312-0967. Pharmaceutical review. 2018. № 1 
Фармацевтична технологія, біофармація, гомеопатія Pharmaceutical technology, biopharmacy, homeopathy

використання екстракту кореня солодки при захворюваннях, спричинених патогенними для людини аденовірусами [7].

Таким чином, на підставі проведених досліджень обґрунтовано раціональні концентрації діючих речовин у складі назального гелю «Фіторин-плюс»: екстракту кореня солодки - 3 \%, ефрірної олії евкаліпту прутоподібного - 2 \% і есрірної олії сосни сибірської -1 \%.

Отримані дані мікробіологічних досліджень були також підтверджені при подальшому експериментальному вивченні антимікробних і противірусних властивостей готової лікарської форми.

Назальний гель «Фіторин-плюс» готували при кімнатній температурі за загальноприйнятими правилами. 3 огляду на фрізико-хімічні властивості діючих ре- човин, а саме їх розчинність, екстракт кореня солодки вводили до складу гелю у вигляді водного розчину, а ефрірні олії у вигляді розчину в етанолі (96\%).

Висновки. 1. Експериментально обґрунтовано вибір діючих речовин назального гелю під умовною назвою «Фіторин-плюс» для лікування ринітів.

2. На підставі проведених мікробіологічних досліджень обґрунтовано концентрацію екстракту кореня солодки й ефірних олій у складі лікарського препарату. Вперше встановлено наявність противірусної дії екстракту кореня солодки відносно аденовірусу.

3. Розроблений назальний гель на основі екстракту кореня солодки і ефірних олій евкаліпту прутоподібного і сосни сибірської є перспективним для подальшого використання у терапії ринітів.

\title{
ЭКСПЕРИМЕНТАЛЬНОЕ ОБОСНОВАНИЕ СОСТАВА НАЗАЛЬНОГО ГЕЛЯ ПОД УСЛОВНЫМ НАЗВАНИЕМ «ФИТОРИН-ПЛЮС»
}

\author{
И. А. Карпенко, Т. Г. Ярных, О. А. Рухмакова \\ Национальный фрармацевтический университет, Харьков \\ rukhmakovaolga@gmail.com
}

\begin{abstract}
Цель работы. Экспериментальное обоснование состава назального геля под условным названием «Фиторин-плюс». Материалы и методы. С целью определения рациональной концентрации экстракта корня солодки и эсрирных масел эвкалипта прутовидного и сосны сибирской в составе геля были проведены микробиологические исследования на базе кафедры микробиологии, вирусологии и иммунологии Национального фрармацевтического университета в лаборатории микробиологических и иммунологических исследований методом дифрфузии в агар с использованием эталонных штаммов микроорганизмов: Staphylococcus aureus ATCC 25923, Escherichia coli ATCC 25922, Pseudomonas aeruginosa ATCC 27853, Candida albicans ATCC 885/653.

Исследования по изучению противовирусной активности осуществлялись на базе Государственного учреждения «Институт микробиологии и иммунологии им. И. И. Мечникова АМН Украины».

Результаты и обсуждение. На основании проведенных исследований были обоснованы рациональные концентрации действующих веществ в составе назального геля «Фиторин-плюс»: экстракта корня солодки - 3 \%, эсирного масла эвкалипта прутовидного - 2 \%, эфирного масла сосны сибирской - 1 \%. Полученные данные были подтверждены при дальнейшем экспериментальном изучении антимикробных и противовирусных свойств готовой лекарственной срормы. Выводы. Экспериментально обоснован выбор действующих веществ назального геля под условным названием «Фиторин-плюс» для лечения ринитов. На основании данных проведенных микробиологических исследований обоснована концентрация экстракта корня солодки и эфирных масел в составе лекарственного препарата. Впервые установлено наличие противовирусного действия экстракта корня солодки по отношению каденовирусу. Показано, что разработанный назальный гель является перспективным для дальнейшего использования в терапии ринитов.
\end{abstract}

Ключевые слова: назальный гель; солодка голая; эфирные масла; состав; экспериментальное обоснование.

\section{EXPERIMENTAL JUSTIFICATION OF THE NASAL GEL'S COMPOSITION UNDER THE CONVENTIONAL NAME "PHYTORIN-PLUS"}

\author{
I. A. Karpenko, T. G. Yarnykh, O. A. Rukhmakova \\ National University of Pharmacy \\ rukhmakovaolga@gmail.com
}

The aim of the work. The experimental justification of the nasal gel's composition under the conventional name "Phytorin-plus". Materials and Methods. In order to determine the rational concentration of the extract of licorice root and essential oils

ISSN 2312-0967. Фармацевтичний часопис. 2018. № 1 
of Eucalyptus and Siberian pine in the gel microbiological studies were conducted on the basis of the Department of Microbiology, Virology and Immunology of the National University of Pharmacy in the laboratory of microbiological and immunological studies by diffusion to agar using reference strains of microorganisms Staphylococcus aureus ATCC 25923, Escherichia coli ATCC 25922, Pseudomonas aeruginosa ATCC 27853, Candida albicans ATCC 885/653.

Studies of antiviral activity were carried out on the basis of the State Institution "Institute of Microbiology and Immunology named by I. I. Mechnykov of the Academy of Medical Sciences of Ukraine".

Results and Discussion. Based on the studies, the rational concentrations of active ingredients in the nasal gel "Phytorin -plus" were justified: extract of licorice root $-3 \%$, essential oil of Eucalyptus - $2 \%$, essential oil of Siberian pine - $1 \%$. The data obtained were confirmed with further experimental study of antimicrobial and antiviral properties of the finished dosage form.

Conclusions. The choice of the active substances of nasal gel under the conventional name "Phytorin-plus" for the treatment of rhinitis has been experimentally proved. Based on the data of the conducted microbiological studies, the concentrations of the extract of licorice root and essential oils in the composition of the medicinal preparation were grounded. The presence of antiviral action of licorice root extract in relation to adenovirus was established for the first time. It was shown that the developed nasal gel is promising for further use in the therapy of rhinitis.

Key words: nasal gel; licorice; essential oils; composition; experimental substantiation.

\section{Список літератури}

1. Ненашева Н. М. Достижение контроля аллергического ринита с помощью ступенчатой терапии / Н. М. Ненашева // Эфрфективная фрармакотерапия. Пульмонология и оториноларингология. - 2015. - № 1. - С. 14-22.

2. Ozdoganoglu T. Quality of life in allergic rhinitis / T. Ozdoganoglu, M. Songu, H. M. Inancli // Ther. Adv. Respir. Dis. - 2012. - No. 6. - P. 25-39.

3. Косаковский А. Л. Аллергический ринит: этиология, патогенез, клинические проявления и патогенетически обоснованная терапия / А. Л. Косаковский, Ю. В. Гавриленко // Український медичний часопис. Актуальні питання клінічної практики. - 2013. - № 6 (98). - С. 23-27. 4. Особенности ринита при ОРВИ / С. В. Зайков, Л. В. Кузнецова, Л. С. Осипова, А. П. Назаренко // Український медичний часопис. Актуальні питання клінічної практики. - 2013. - № 5 (97). - С. 14-17.

\section{References}

1. Nenasheva NM. [Achieving control of allergic rhinitis with the help of stepwise therapy]. Effektivnaya farmakoterapiya. Pulmonologiya i otorinolaringologiya. 2015;1: 14-22. Russian.

2. Ozdoganoglu T, Songu M, Inancli HM. [Quality of life in allergic rhinitis]. Ther. Adv. Respir. Dis. 2012;6: 25-39.

3. Kosakovskiy AL, Gavrilenko YuV. [Allergic rhinitis: etiology, pathogenesis, clinical manifestations and pathogenetically based therapy]. Ukrainskyi medychnyi chasopys. Aktualni pytannia klinichnoi praktyky. 2013;6(98): 23-7. Ukrainian.

4. Zaikov SV, Kuznetsova LV, Osipova LS, Nazarenko AP. [Features of rhinitis in acute respiratory viral infections]. Ukrainskyi medychnyi chasopys. Aktualni pytannia klinichnoi praktyky. 2013;5(97): 14-7. Ukrainian.
5. Рухмакова О. А. Перспективи використання солодки голої в якості імуномодулюючого засобу у педіатрії / О. А. Рухмакова, Т. Г. Ярних // Актуальні питання фрармацевтичної і медичної науки та практики. - 2014. № 1 (14). - С. 47-49.

6. Определение биологической активности эфирных масел с помощью биотест-систем in vitro / В. А. Дубинская, Н. А. Поляков, А. А. Ефрремов, Е. А. Ефрремов // Химия растительного сырья. - 2013. - № 3. - С. 149-153. 7. Пат. на корисну модель № 95890 Україна, МПК (2011) А61K36/48, А61P31/12. Застосування екстракту солодкового кореня як противірусного засобу по відношенню до аденовірусів 3-го типу у педіатрії / Ярних Т. Г., Рухмакова О. А., Панченко Л. О.; заявн. і патентовл. НФаУ. - № u 201408184 ; заявл. 21.07.14 ; опубл. 12.01.15. Бюл. № 1. - 4 c.

5. Rukhmakova OA., Yarnykh TH. [Prospects for the use of licorice bare as an immunomodulatory agent in pediatrics]. Aktualni pytannia farmatsevtychnoi i medychnoi nauky ta praktyky. 2014;1(14): 47-9. Ukrainian.

6. Dubinskaya VA, Polyakov NA, Efremov AA, Efremov EA. [Determination of the biological activity of essential oils with the help of biotest systems in vitro]. Khimiya rastitelnogo syrya. 2013;3: 149-53. Russian.

7. Patent to utility model No. 95890 Ukraine, IPC (2011) A61K36/48, A61P31/12. Application of licorice root extract as an antiviral agent in relation to type 3 adenoviruses in pediatrics. Yarnykh TG, Rukhmakova OA, Panchenko LO; an application and patents. NFaU - No. u 201408184; stated. July 21, 14; has published 12.01.15; 1: 1-4. 